\title{
Isopods (Crustacea, Malacostraca) from International Minho River, Iberian Peninsula
}

\author{
Nuno Miguel Araújo Gomes ${ }^{1,2 *}$, Dimítri De Araújo Costa ${ }^{1,2}$, Harold Casalís Cantallo ${ }^{1}$ Tiago José Andrade \\ Ribeiro $^{1}$ and Carlos Antunes ${ }^{1,2}$ \\ ${ }^{1}$ Interdisciplinary Centre of Marine and Environmental Research (CIIMAR), University of Porto, Portugal \\ ${ }^{2}$ Aquamuseu do Rio Minho, Parque do Castelinho, Portugal
}

Submission: March 30, 2021; Published: May 07, 2021

Corresponding author: Nuno Miguel Araújo Gomes, Interdisciplinary Centre of Marine and Environmental Research (CIIMAR), University of Porto, Terminal de Cruzeiros do Porto de Leixões, Avenida General Norton de Matos, s/n, 4450-208 Matosinhos, Portugal.

Email: Nuno@ciimar.up.pt

\section{Abstract}

Isopods are a common, diverse, and abundant group of the littoral and estuarine invertebrate fauna. This study presents a survey on the species of isopods found on the Minho River estuary, Iberian Peninsula, using plankton net, glass eel fishing bycatch, grab sampler, and sein net sampling methods. A total of 248 specimens were analysed belonging to five families with 13 species in 10 genera. Brief diagnosis, ecological notes, species distributions, figures and a key to species identifications are provided aiming to provide taxonomic support on future projects on this area.

Keywords: Atlantic Ocean; Distribution; Estuary; Isopoda; Taxonomy

\section{Introduction}

Order Isopoda (Crustacea) is a diverse group with more than 10.000 valid species according to the World Register of Marine Species database [1], occupying all habitats from marine deep waters to freshwater aquifers or from deserts to mountains [2]. Isopods, known also as pillbugs, slaters and woodlice, represent a group of high range of polymorphism, characterized by a dorsoventrally compressed body shape, subdivided in three parts, a cephalon with two pairs of antennae, a pereon of seven segments with seven pairs of pereopods, a pleon of five segments with five pairs of pleopods, and a pleotelson with one pair of uropods [3]. Sexual dimorphism is present in some species, in which females carry the juveniles in a ventral marsupium; juveniles or manca lack the last pair of pereopods [2]. Meanwhile, deep sea individuals have adaptative structures, such as lack of eyes, antennae same or larger than body size, pereopods much larger than body size [4,5]. Some groundwater species with lateral compression [6], and loss of body shape in some parasitic species, i.e. pereonites become folded indistinct and with rudimentary or absent pereopods [7].

Portuguese isopod aquatic fauna remains poorly known despite recent taxonomic work, including groundwater species, e.g. [8-10], on shallow coastal waters e.g. and works from deep seas exploration expeditions on the continental Canyons and
Portuguese archipelagos of Azores, e.g. [11-13]. Macroinvertebrate surveys on the Minho River started on 1982 [14], but have been scarce with only a few works on macrobenthic ecology or specimens collected through glass eel fishing bycatch [15-17]. In this study we provide diagnostics features for the isopod fauna collected on the Minho River estuary, belonging to 13 species, 10 genera, five families and three suborders, with ecological notes, global and Portuguese distributions, and a key for species identification.

\section{Materials and Methods}

\section{Study Area}

Minho River, located at the northwest of the Iberian Peninsula, originates in the Meira mountains (Spain), with around $300 \mathrm{~km}$ of extension [18]. The international section located on the last $70 \mathrm{~km}$ represents the northwest section Spanish/Portuguese border, culminating on an estuary flowing into the Northeast Atlantic Ocean. This estuary area has a length of approximately $40 \mathrm{~km}$, with a total area of $23 \mathrm{~km}^{2}$ [16], with a mesotidal partially mixed system tending towards a salt wedge estuary during the high floods [19], providing for a variety of habitats such as salt marshes, mudflats, sandflats and freshwater making for a high species diversity. Due 
to its ecological importance, the international Minho River section (including the estuarine zone) was designated as a Natura 2000 site and as an Important Bird Area [20,21].

\section{Methods}

All isopod specimens were collected during previous campaign samplings at the International Minho River, on the estuarine zone (Figure 1), with following methods: 1) plankton net with a $200 \mu \mathrm{m}$ mesh, in Caminha, Portugal (41 $\left.{ }^{\circ} 52^{\prime} 32.40^{\prime \prime} \mathrm{N} / 8^{\circ} 51^{\prime} 30.39^{\prime \prime} \mathrm{W}\right)$ on May, 2020; 2) glass eel fishing bycatch, in Caminha, Portugal $\left(41^{\circ} 52^{\prime} 59.00^{\prime \prime} \mathrm{N} / 8^{\circ} 50^{\prime} 14.00^{\prime \prime} \mathrm{W}\right)$, during a new moon night on flood tides, using stow net (length of float lines $10 \mathrm{~m}$, bottom anchored lead line of $15 \mathrm{~m}$, height $8 \mathrm{~m}$, mesh size $1-2 \mathrm{~mm}$, covering an area of $50 \mathrm{~m}^{2}$ ), on April, 2020;3) on sediment sampling with a Van Veen grab sampler in Caminha, Portugal (41 ${ }^{\circ} 53^{\prime} 23.00^{\prime \prime} \mathrm{N} /$ $8^{\circ} 50^{\prime} 09.92$ "W), on September, 2020; 4) in gut contents of Alosa

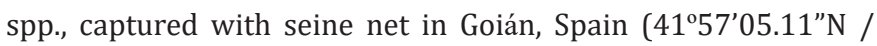
$8^{\circ} 44^{\prime} 53.39$ 'W), on November, 2020. Granulometry calculation was performed on GRADISTAT software version 8.0 [22].

Isopod identification was based on specialized literature e.g. $[3,7,23,24]$. Synonym's compilation was performed, mainly according to WORMS database and data on species description compiled from taxonomic studies e.g. [25,26]. Type material and locality data were obtained from Global Biodiversity Information Facility [27] or from original descriptions, if available. Institution acronyms on type material descriptions are: NHMUK, Natural History Museum, London; NHMD, Natural History Museum of Denmark; ZMB, Museum fur Naturkunde Berlin; RMNH, Naturalis Biodiversity Center. All specimens were photographed with a Nikon Digital Sight D5-L1 camera and a Nikon SMZ800 stereomicroscope. Specimens deposited at Arthropod Collection from Natural History Museum of the Iberian Peninsula (NatMIP - "Museu de História Natural da Península Ibérica"), sited at Aquamuseu do Rio Minho, Vila Nova de Cerveira, North Portugal. (Figure 1)

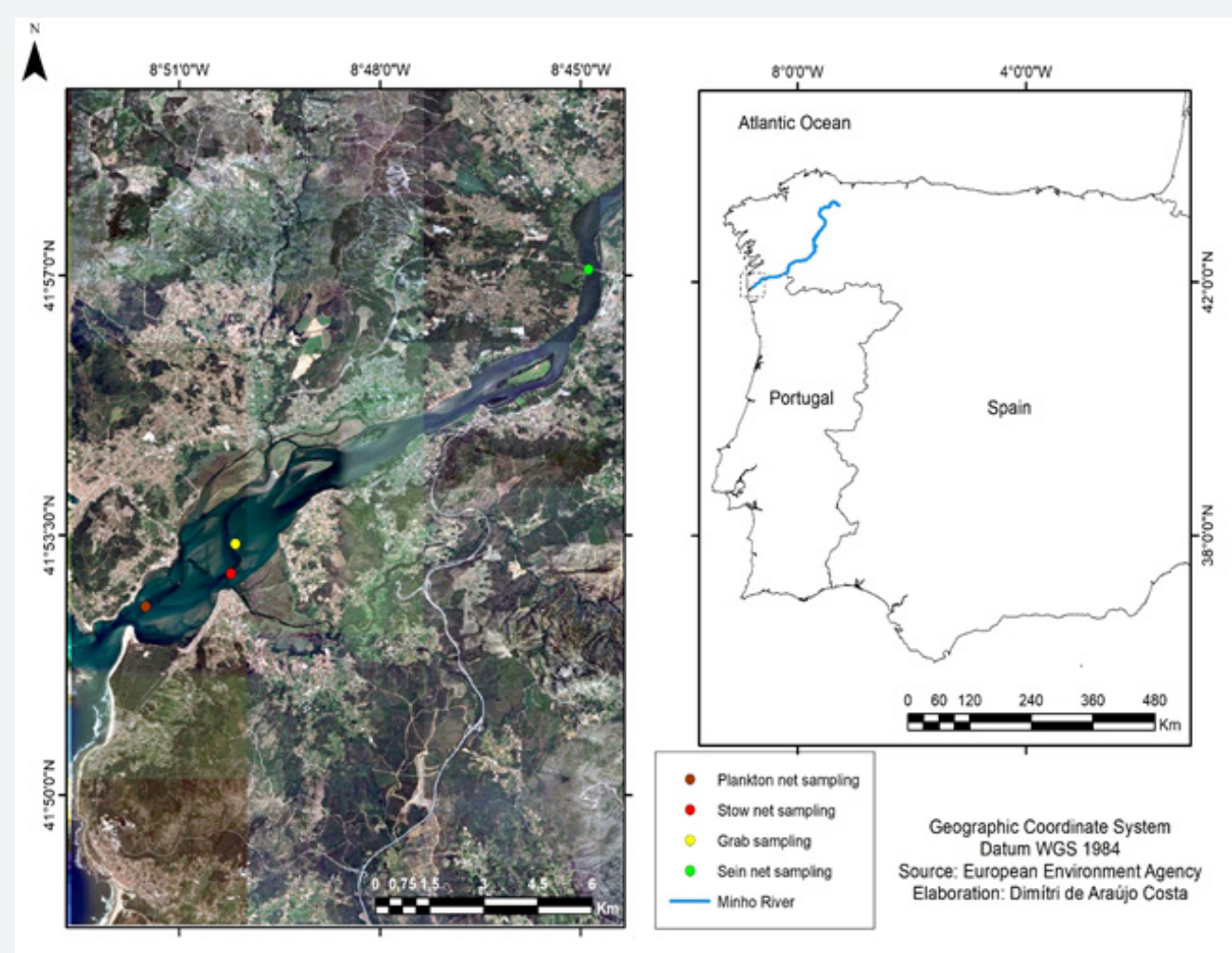

Figure 1: Study Area. Minho River (Iberian Peninsula), with highlight on the sampling points and methods in the international zone, satellite images: Bing Maps.

\section{Results}

A total of 248 individuals were recorded from the Minho River estuary, 245 from glass eel fishing bycatch, 1 from sediment sampling, 1 from plankton sampling and 1 from the gut content of Alosa spp., belonging to 13 species, 10 genera, five families and three suborders, as listed below.
Phylum Arthropoda Siebold, 1848

SubPhylum Crustacea Brünnich, 1772

SuperClass Multicrustacea Regier, Shultz, Zwick, Hussey, Ball, Wetzer, Martin \& Cunningham, 2010

Class Malacostraca Latreille, 1802 
SubClass Eumalacostraca Grobben, 1892

SuperOrder Peracarida Calman, 1904

Order Isopoda Latreille, 1817

SubOrder Cymothoida Wägele, 1989

SuperFamily Anthuroidea Leach, 1914

Family Anthuridae Leach, 1814

I. Cyathura carinata (Krøyer, 1847) (Figure 2 A-B)

Cyathura carinata Richardson, 1905: 63-66, figs. 47-50 [27]; Cleret, 1960: 434-450, figs. I-XII [28]; Naylor, 1972: 20-21, fig. 6D-F [7].

Synonyms: Anthura carinata Krøyer, 1847: 402-407 [26].

Anthura brunnea in Verrill, Smith \& Harger, 1883: 278 [29].

\section{- Type Material}

DENMARK • None designated [30]; Copenhagen [26].

\section{- Material Examined}

PORTUGAL 4 adults, size range 9 to $16 \mathrm{~mm}$; International Minho River, Caminha; 4152'59.00”N, 850'14.00”W; 6 Apr. 2020; glass eel fishing bycatch; NatMIP-CMIs001 16 adults; same data as for preceding; NatMIP-CMIs 000225 adults; same data as for preceding; NatMIP-CMIs 000326 adults; same data as for preceding; NatMIP-CMIs 0004.

\section{- Diagnosis}

Anthurid with punctiform eyes; body elongated with keeled pereon; larger first pair of pereopods with a tooth on the inferior propodus margin; telson ovate gradually converging to a curved apex (Figure 2B); antennules on both male and female of the same size; male with copulatory stylet on the second pleopod pair $[3,26,27]$.

\section{- Global distribution}

Northeast Atlantic Ocean; south and west coasts of England, South Wales, Ireland; southwest Baltic and Mediterranean [3].

\section{- Distribution in Portugal}

Species recorded on the Minho, Lima, Cávado, Douro, Mondego and Tejo rivers, Ria de Aveiro, Ria Formosa and in Sines [16,3138].

\section{- Ecological notes}

Often found at brackish or freshwater habitats, e.g., muddy bottom, up to $5 \mathrm{~m}$ depth $[3,39]$.

SuperFamily Cymothooidea Leach [25]

Family Cirolanidae Dana, 1852

II. $\quad$ Eurydice affinis Hansen, 1905 (Figure 2 C-D).
Eurydice affinis Hansen 1908:367-368, Pl. 35 fig, 2A-K; Naylor, 1972: 27, fig. 8E [7]; Wolff, 1966: 223-225, figs. 2A, 3A [39].

- Type material

- Syntypes

FRANCE - of St. Lunaire; NHMD-86713 • FRANCE • Cartenet; 1 Aug. 1890; NHMD-86714 • FRANCE • St. Lunaire; NHMD-86715 - FRANCE • Cartenet; 1 Aug. 1890; NHMD-86716 • FRANCE • Cartenet; NHMD-83021 • FRANCE • St. Lunaire; ZMB-11394.

\section{- Material Examined}

PORTUGAL • 25 adults, size range 11 to $15 \mathrm{~mm}$; International Minho River, Caminha; 4152'59.00”N, 850'14.00”W; 6 Apr. 2020; glass eel fishing bycatch; NatMIP-CMIs0017) • 19 adults; same data as for preceding; NatMIP-CMIs $0018 \bullet 19$ adults; same data as preceding; NatMIP-CMIs 0019.

\section{- Diagnosis}

Pereonite 6 with posterior angle of coxal plate acute; chromatophores (black colour) restricted to dorsal surface (Figure 2C-D); antenna scarcely reaching lateral angle of pereon (Figure 2C); endopods of uropods shorter than telson $[3,7,40]$.

\section{- Global Distribution}

From the North Sea to Iberian Peninsula; British Isles and Mediterranean [3].

\section{- Distribution in Portugal}

Species collected along the west coast, on the south coast and Azores [10,41-43].

\section{- $\quad$ Ecological Notes}

Found in sand beaches, on intertidal High Water Neap Tide (HWNT) zone to $60 \mathrm{~m}$ depth; free movement with the rising tide and may be present among sand grains; feeding in the water column at high tide and at night [3].

\section{- $\quad$ Remarks}

Despite being typically found on sandy beaches, this marine species presence was probably due to drifting towards the net due to the flood tides entering the estuary.

Family Gnathiidae Leach [25]

\section{Paragnathia formica (Hesse, 1864) (Figure 2E-F).}

Paragnathia formica Naylor, 1957: fig. 1A-E [44]; Naylor, 1972: 18, figs. 4A-C, 5A [7]

Synonyms: Anceus formica Hesse, 1864: 39-41, Pl. I fig. 28, Pl. II fig. 15, Pl. III fig. 5-7 [43]

Anceus halidaii Bate \& Westwood 1866 [45].

Paragnathia halidaii Bate \& Westwood 1866: 202-208 [45]. 


\section{- Type Material}

Unknown.

\section{- Material Examined}

PORTUGAL - 2 adult juveniles (praniza) with $4 \mathrm{~mm}$; International Minho River, Caminha; 41 52 '59.00”N, 8'50'14.00"W; 6 Apr. 2020; glass eel fishing bycatch; NatMIPCMIs 0029 • 1 juvenile (zuphea); International Minho River,

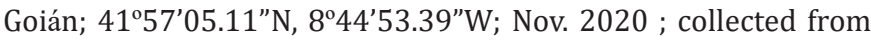
the gut content of Alosa spp. 11 juvenile (zuphea) with $2.6 \mathrm{~mm}$; International Minho River, Caminha; $41^{\circ} 52^{\prime} 40^{\prime \prime} \mathrm{N}, 8^{\circ} 51^{\prime} 30^{\prime \prime} \mathrm{W}$; May 2020; on a plankton net.

\section{- Diagnosis}

Five-segmented pylopods (in males); telson rounded posteriorly (Figure 2F); early pranizas body length $2.5-5.0 \mathrm{~mm}$ and with antennal flagellum of 8 segments; females and praniza with pereonites 3-5 fused and inflated [3,7].

\section{- Global Distribution}

Northeast Atlantic, from Scotland to Morocco [3].

\section{- Distribution in Portugal}

Species recorded on Azores, Aveiro and the estuaries of the Mondego and Tejo rivers [35,46,43,47].

\section{- $\quad$ Ecological Notes}

Lives at estuarine muddy banks; late pranizas with parasitic behaviour on inshore or on flatfishes (order Pleuronectiformes); Adults occur in galleries, typically with a male near the entrance and 10 to 20 females on the inner part of the gallery [3,7].

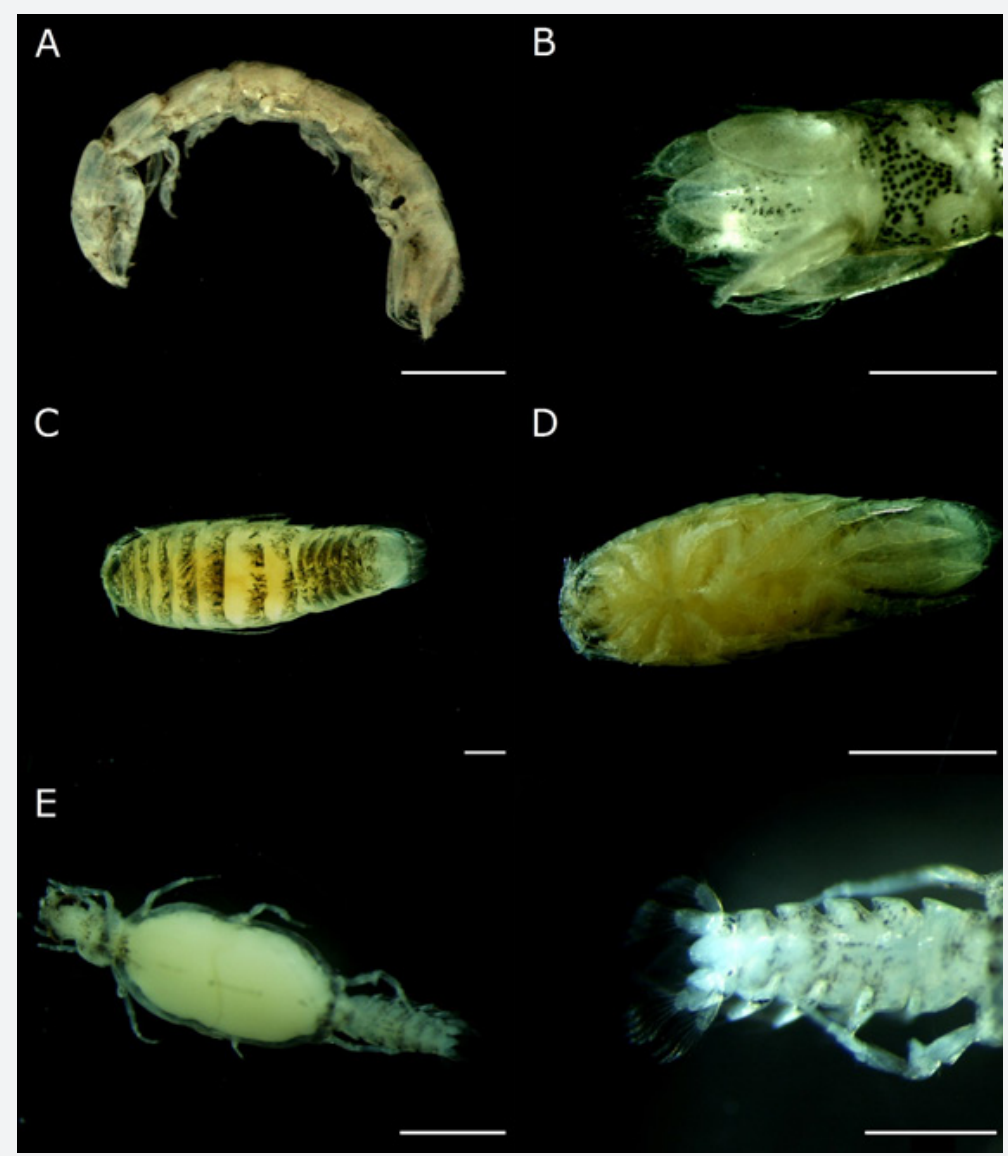

Figure 2: Cyathura carinata (Krøyer, 1847): dorsal view (A), pleotelson (B); Eurydice affinis Hansen, 1905, dorsal view (C), ventral view (D); Paragnathia formica (Hesse, 1864), dorsal view (E), telson (F). Scales: A-C,E: 1mm; D: 5mm; F: 0.5mm.

SubOrder Sphaeromatidea Wägele, 1989

SuperFamily Sphaeromatoidea Latreille, 1825

Family Sphaeromatidae Latreille, 1825

IV. Dynamene bidentata Adams, 1800 (Figure 3A).

Dynamene bidentata Holdich, 1968: 408-410, figs. 1, 2A1, 2B5,
2C1, 3, 4, 5 [24]; Holdich, 1970: fig.8 [48]; Naylor, 1972: 35, fig. 11A-B [7]; Holdich, 1976: fig. 2A-B [49]; Vieira et al. 2016: 5-7, figs. 1, 2A-B [50].

Synonyms: Oniscus bidentatus Adams, 1800: 8, Tab. II figs. 3-4 [47].

Nesaea bidentata Leach, 1814: 405 [25].. 
Naesa bidentata Desmarest, 1825: 295, Pl.47 fig. 2 [52]; Bate \& Westwood 1866: 431-432 [45]..

- Type Material

- Neotype

WALES • Milford Haven; 10 Jan. 1967; NHMUK 1968.1.3.1.

\section{- Material Examined}

PORTUGAL - 1 \& adult with 2.5mm; International Minho River, Caminha; 4152'59.00”N, 850'14.00”W; 6 Apr. 2020; glass eel fishing bycatch; NatMIP-CMIs 0028.

\section{- Diagnosis}

Males pleotelson with two bosses joined at the bases, bidentate process sparsely rugose dorsally becoming narrower apically; females with pleotelson dome smoothly rounded on side view; length up to $7 \mathrm{~mm}$ in males, $6 \mathrm{~mm}$ in females $[3,7,50]$.

\section{- Global Distribution}

Northeast Atlantic from France and British Isles to Morocco, Tenerife, and Gran Canaria [50].

\section{- Distribution in Portugal}

Species recorded along the West coast $[33,57]$.

\section{- $\quad$ Ecological Notes}

Common in rocky shores, from MTL to LWS; juveniles on intertidal algae that they feed upon; adults in rock crevices or empty tests of the barnacle Perforatus perforatus (Bruguière, 1789 ) in which they breed; each male usually with several females $[3,50]$.

\section{Dynamene magnitorata Holdich, 1968 (Figure 3B-C)}

- $\quad$ Dynamene magnitorata Holdich, 1968: 417-418 [24], figs. 2A4, 2B3, 2C3, 10; Holdich, 1976: fig.4A-B [49]; Vieira et al. 2016: 11-13, figs. 2C-D, 3C-D [50].

- Type Material

- Holotype

FRANCE • 1 कా; Roscoff, Bretagne; 16 Sep. 1958; RMNH. CRUS.I.1695.

\section{- $\quad$ Paratypes}

FRANCE • Roscoff, Bretagne; NHMUK 1968.1.3.17-18 • FRANCE • 8; Roscoff, Bretagne; 16 Sep. 1958; RMNH.CRUS.I.1696 - FRANCE • 1; Pointe Barfleur, Normandie; 26 Oct. 1958; RMNH. CRUS.I.1697.

\section{- Material Examined}

PORTUGAL - 1 \& adult, size 4.5mm; International Minho River, Caminha; 4152'59.00”N, 850'14.00”W; 6 Apr. 2020; glass eel fishing bycatch; NatMIP- CMIs 0021 - 2 \& adults, size range 4 to $4.5 \mathrm{~mm}, 1$ of adult with $5 \mathrm{~mm}$ and 1 क pre-adult with $4 \mathrm{~mm}$;

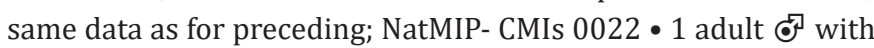

4.5mm, same data as for preceding NatMIP- CMIs 0023.

\section{- Diagnosis}

Pleotelson on males with two bosses fused by a stalk, in which each boss with a prominent, apical, subsidiary projection, bidentate processes apically tuberculate with similar width along their lengths (Figure 3B); females with a mid-dorsal projection at posterior margin of pleotelson (Figure $3 \mathrm{C}$ ); maximum males' length $6 \mathrm{~mm}, 4.8 \mathrm{~mm}$ in females; lobes on maxillipedal palp thick, first longer than third $[3,24]$.

\section{- Global Distribution}

Northeast Atlantic, from France to the Iberian Peninsula; British islands; Macaronesian archipelagos; Mediterranean Sea along European and African coasts and Egypt [51].

\section{- Distribution in Portugal}

Present on all mainland Portuguese coastline, Madeira and Azores archipelagos [50-53].

\section{- Ecological notes}

Juveniles amongst lower shore and upper sublittoral algae, e.g., Chondrus crispus Stackhouse, 1797, and coralline ones; adults live in crevices, in barnacle tests (Balanus crenatus Bruguière, 1789), amongst clumps of ascidians, in sponges channels (e.g., Halichondria spp.), and associated with seagrass Zostera sp. [53].

\section{Ischyromene lacazei Racovitza, 1908 (Figure 3D-E).}

- Ischyromene lacazei Racovitza, 1908: 64, figs. 1-3 [53]; Holdich, 1968: fig. 12 [24]; Schuller \& Wägele 2005: 165-166, fig. 1 [54].

\section{- Type Material}

- $\quad$ Syntypes

FRANCE • Banyuls-sur-Mer; 42.5N, 3.1E; 10 May 1909; ZMB 13768 • FRANCE • Banyuls-sur-Mer; NHMD-84847.

\section{- Material Examined}

PORTUGAL 1 adult with 3.5mm; International Minho River,

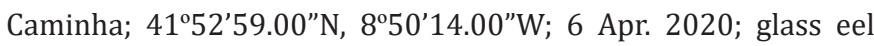
fishing bycatch; NatMIP-CMIs 0020.

\section{- Diagnosis}

First pleopod covers pleopods 2-5; pleon smooth and pleotelson with conspicuous tuberculation; pleotelson almost triangular shape, with the median region vaulted on both sides of the midline; apical foramen opens dorsally, visible as an open slit from above (Figure 3E); both uropod rami apically rounded [54].

\section{- Global Distribution}

Mediterranean and Iberian Peninsula [54].

\section{- Distribution in Portugal}

Species recorded along the West Portuguese coast [51].

\section{- $\quad$ Ecological Notes}


Found at marine shallow waters; usually associated with barnacles [54].

\section{Lekanesphaera hookeri (Leach, 1814) (Figure 3F).}

Lekanesphaera hookeri Jacobs, 1987: 51-55, fig. 17 [55].

Synonyms: Sphaeroma hookeri Leach, 1814: 433 [25]; Desmarest, 1825: 300; Bate \& Westwood 1866: 410-411 [45]; Jansen, 1970: fig.2 [54]; Naylor, 1972: 32, fig. 10G-H [7].

Exosphaeroma pulchellum Colosi, 1921: 3-4 [57].

\section{- Type Material}

ENGLAND • Norfolk [25]; unknown data.

\section{- Material Examined}

PORTUGAL 1 adult with $4 \mathrm{~mm}$; International Minho River,

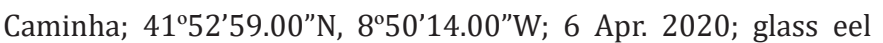
fishing bycatch; NatMIP-CMIs 0027.

\section{- Diagnosis}

Pereopod 1 with around to 20 setae smooth-like on ischium and on merus; uropods with external margin of exopod almost smooth; pleotelson dorsal surface with two longitudinal rows of tubercles; antenna peduncle with 5 articles and flagellum with 12-16 articles ; interior endite of maxilliped with fringe of robust, plumose setae with swollen base on semi-circular distal margin; pleotelson subapically concave and slightly upcurved in side view; uropod reaching slightly beyond the posterior margin of pleotelson; maximum males length $10.5 \mathrm{~mm}, 8.5 \mathrm{~mm}$ in females $[3,7,55]$.

\section{- Global Distribution}

Northeast Atlantic from Poland, including Baltic Sea to Morocco; Mediterranean; Adriatic and Aegean Sea [54].

\section{- Distribution in Portugal}

Species recorded on Aveiro [35] and on the Mondego estuary [46].

\section{- $\quad$ Ecological Notes}

In estuaries near to upper limit of Extreme High-Water Springs (EHWS), euryhaline species, usually in ditches brackish water, on riverbanks, on muddy bottoms, under stones, and amongst seagrasses [3].

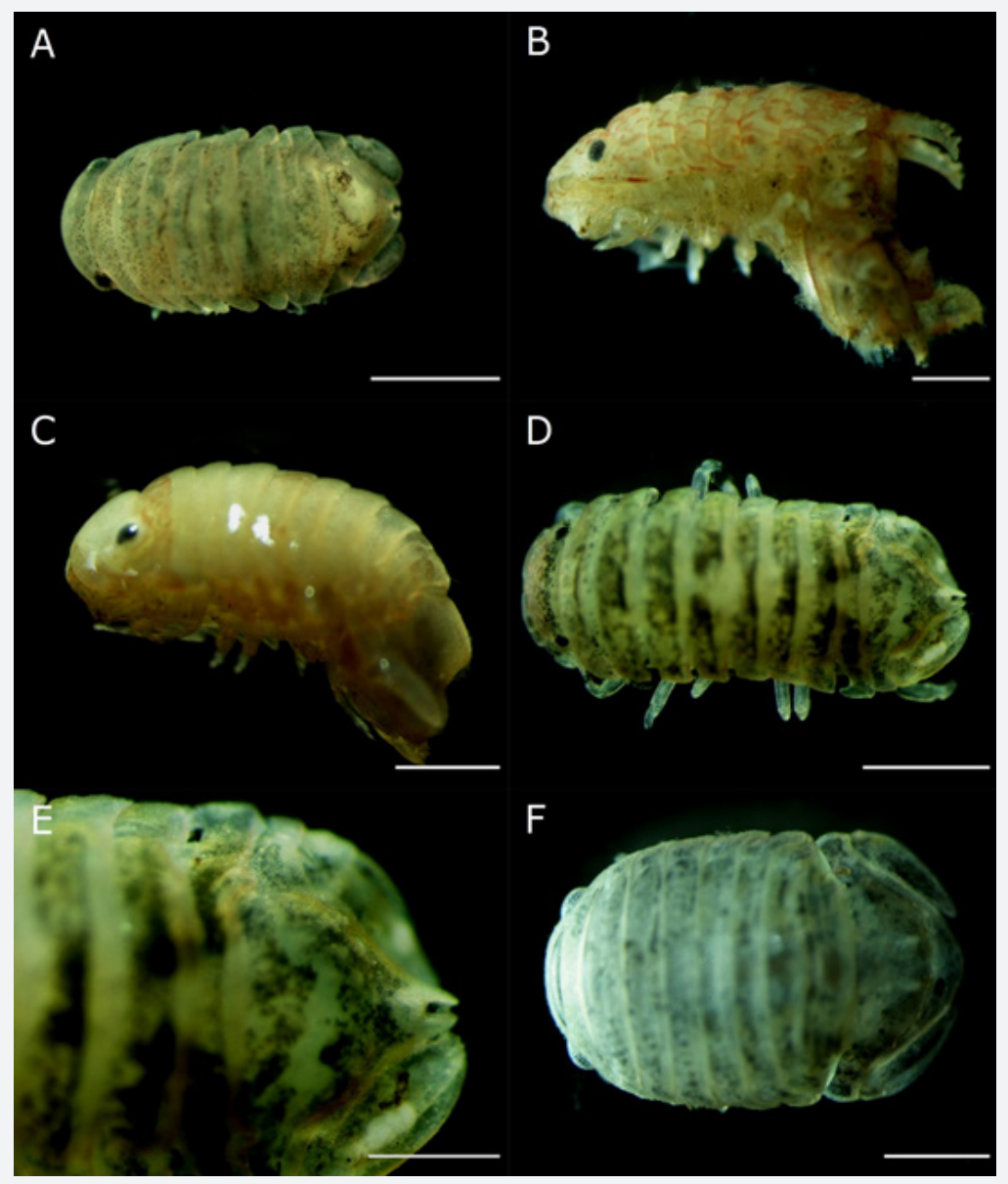

Figure 3: Dynamene bidentata (Adams, 1800), female dorsal view (A); Dynamene magnitorata Holdich, 1968: male (B), female (C); Ischyromene lacazei Racovitza, 1908: dorsal view (D), pleotelson (E); Lekanesphaera hookeri (Leach, 1814): dorsal view (F). Scales: A-D,F: $1 \mathrm{~mm}$; E: 0,5mm. 
VIII. Lekanesphaera levii (Argano \& Ponticelli, 1981) (Figure 4A)

Lekanesphaera levii Jacobs, 1987: 46-48, fig. 15 [55]

Synonyms: Sphaeroma monodi Naylor, 1972: 34, fig. 10I-J [7]

Sphaeroma levii Argano \& Ponticelli 1981: 229-232 [58

- Type Material

ROMANIA • Constanta [58]; Unknown data.

\section{- Material Examined}

PORTUGAL - 1 adult with 4mm; International Minho River, Caminha; 4152'59.00”N, 850'14.00”W; 6 Apr. 2020; glass eel fishing bycatch; NatMIP- CMIs $0024 \cdot 7$ adults, size range 2.7 to $4 \mathrm{~mm}$; same data as for preceding; NatMIP-CMIs $0025 \bullet 7$ adults; same data as for preceding; NatMIP-CMIs 0026.

\section{- Diagnosis}

Pereopod 1 with up to 50 setae smooth-like on ischium, around 60 on merus, and 3-8 in a distal row on the propodus; first three pereopods, and maxilliped palp (with prominent lobes on articles 2-4) with sparsely plumose setae; uropods usually with 6-7 slight striations on outer margin of exopod; pleotelson with smooth dorsal surface, subapically concave and slightly upcurved on side view for both sexes, posterior margin narrower in males; males up to $12 \mathrm{~mm}$, females $8 \mathrm{~mm}[7,55,59]$.

\section{- Global Distribution}

Northeast Atlantic from Belgium to the Mediterranean and Southwest British coast $[3,55]$.

\section{- Distribution in Portugal}

Common along the entire coast $[14,34,55]$ and in Óbidos Lagoon [60].

\section{- $\quad$ Ecological Notes}

Brackish species occurring between Mean Tide Level (MTL) and Low Water Neap (LWN), under stones or in rock crevices [7].

IX. Lekanesphaera rugicauda (Leach, 1814) (Figure 4B).

Lekanesphaera rugicauda Jacobs, 1987: 48-50, fig. 16 [54].

Synonym: Sphaeroma rugicauda Leach, 1814: 405,433 [25]; Desmarest, 1825: 300-301; Bate \& Westwood 1866: 408-409 [45]; Naylor, 1972: 34, fig. 10D-F [7].

- Type Material

- Syntype

SCOTLAND • 4; Argyll, Ulva Island; NHMUK 1979.424.

- Material Examined

PORTUGAL -2 adults, size range 14 to $15 \mathrm{~mm}, 2$ juveniles, size range 2 to $3 \mathrm{~mm}$; International Minho River, Caminha; $41^{\circ} 52^{\prime} 59.00^{\prime \prime} \mathrm{N}, 8^{\circ} 50^{\prime} 14.00^{\prime \prime} \mathrm{W} ; 6$ Apr. 2020; glass eel fishing bycatch; NatMIP-CMIs $0013 \bullet 4$ adults, size range 5 to $15 \mathrm{~mm}, 1$ juvenile with $2 \mathrm{~mm}$; same data as for preceding; NatMIP-CMIs $0014 \bullet 7$ adults, size range 5 to $15 \mathrm{~mm}, 3$ juveniles, size range 2 to $3 \mathrm{~mm}$; same data as for preceding; NatMIP-CMIs $0015 \bullet 7$ adults, 3 juveniles; same data as for preceding; NatMIP-CMIs 0016.

\section{- Diagnosis}

Pereopod 1 with up to 30 smooth setae on ischium, merus with up to about 20 setae, propodus distal row with two or one; uropod exopod outer edge exopod almost smooth; pleotelson dorsal surface covered with tubercles, posterior margin broadly rounded, extending beyond uropods in adult males; males up to $10 \mathrm{~mm}$; females, $7.5 \mathrm{~mm}$ [55].

\section{- Global Distribution}

Northeast Atlantic from Sweden down to Morocco and Azores islands, also on Baltic Sea [54].

\section{- Distribution in Portugal}

Species recorded on Aveiro and Azores [34,41].

\section{- $\quad$ Ecological Notes}

Brackish waters species common in sheltered estuarine situations, from MTL to EHWS occurring mostly on salt marshes with muddy substrates with aquatic vegetation, capable of surviving large fluctuations of temperature and salinity $[3,7,55]$.

\section{Sphaeroma serratum (Fabricius, 1787) (Figure 4C).}

Sphaeroma serratum Jacobs, 1987: 3-19, fig. 3 [54].

Synonyms: Oniscus conglobator Pallas, 1766: 194-195, Tab. XIV figs. 18-19 [62].

Oniscus serratus Fabricius, 1787: 242 [61].

Sphaeroma serrata Leach, 1814: 405 [25].

- Type material

- Neotype

GREENLAND • Bredemilet; 60.7N, 46.7E; 23 Jul. 1912; NHMD85927

\section{- $\quad$ Material Examined}

PORTUGAL • 1 adult with 4mm; International Minho River,

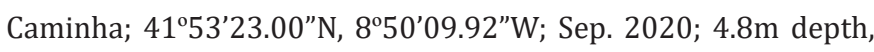
on fine sand, $35.63 \times 10^{-5} \mathrm{ppm}$ salinity; NatMIP-CMIs 0031 .

\section{- Diagnosis}

Palp segments 2-4 robust and lacking lobes, interior margins straight bearing dense fringes of long fine plumose setae; ischium of pereopod 1 with up to about 60 plumose setae in two rows, propodus with a distal row of 15-20 setae; pereopods 1-3 with 
plumose setae; pleotelson smooth, convex inside view; uropods reaching beyond the posterior margin of pleotelson, external margin of exopod uropod with 4-7 pronounced teeth on caudal part; males up to $11.5 \mathrm{~mm}$, and females to $10 \mathrm{~mm}[3,55]$.

\section{- Global Distribution}

Northeast Atlantic from British islands to Morocco; Mediterranean and Black Seas [55].

\section{- Distribution in Portugal}

Recorded on the estuaries of the Minho, Douro, Cávado rivers, Ria de Aveiro, São Julião, Madeira and Azores [30,31,34,51,55,62].

\section{- $\quad$ Ecological notes}

Intertidal, often in sheltered places on High Water Springs (HWS) under stones or in crevices; around MTL on marine coasts $[3,55]$.

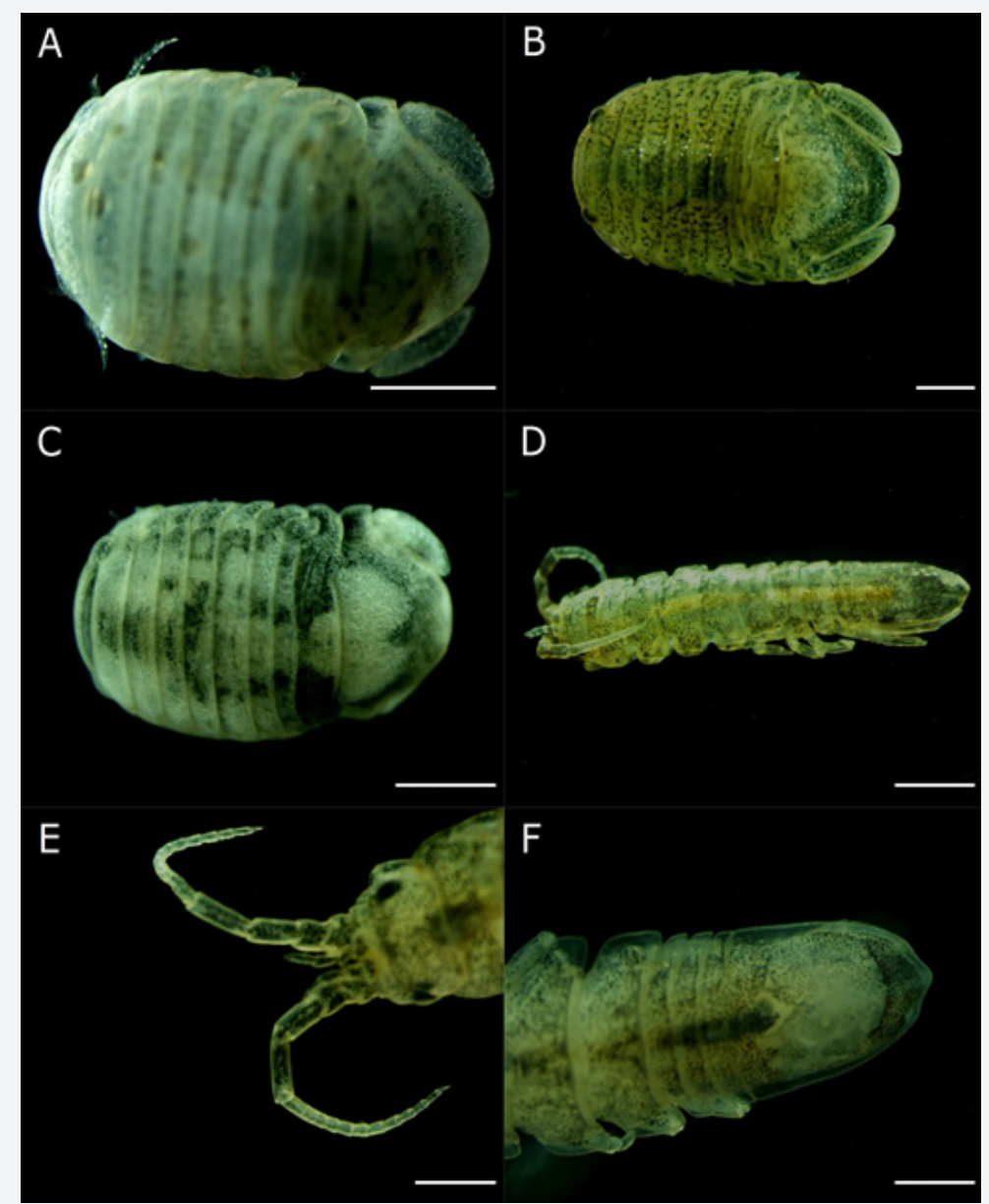

Figure 4: Lekanesphaera levii (Argano \& Ponticelli, 1981): dorsal view (A); Lekanesphaera rugicauda (Leach, 1814): dorsal view (B); Sphaeroma serratum (Fabricius, 1787): dorsal view (C); Idotea chelipes (Pallas, 1766): dorsal view (D), cephalon (E), pleotelson (F). Scales: A,C-F: $1 \mathrm{~mm}$; B: 3mm

SubOrder Valvifera Sars, 1883

Family Chaetiliidae Dana, 1849

XI. Saduriella losadai Holthuis, 1964 (Figure 5A-B)

Saduriella losadai Holthuis, 1964: 30-35, figs. 1-2 [63].

- Type material

- Holotype

SPAIN • 1 \&; Rio Ulla, Lugo; 18 Jul. 1963; RMNH.CRUS.I.1601.

\section{- Paratypes}

SPAIN • 6; Rio Ulla, Lugo; 18 Jul. 1963; RMNH.CRUS.I.1602 • 6; same data as for preceding; RMNH.CRUS.I.1603 • 6; same data as for preceding; RMNH.CRUS.I.1604 - 1; same locality as for preceding; 5 Jul. 1963; RMNH.CRUS.I.1605.

\section{- Material Examined}

PORTUGAL $\bullet 6$ adults, size range 12 to $17 \mathrm{~mm}, 5$ juveniles, size range 4 to $6 \mathrm{~mm}$, coloration light brown with dark speckles or dark brown with lighter speckles; International Minho River, 


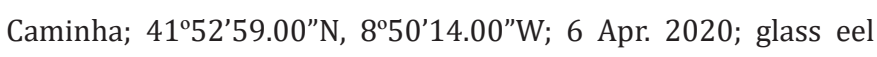
fishing bycatch; NatMIP-CMIs 0009 - 8 adult, size range 12 to $17 \mathrm{~mm}$, same data as for preceding; NatMIP-CMIs $0010 \bullet 9$ adults, 2 juveniles; same data as for preceding; NatMIP-CMIs $0011 \cdot 7$ adults, 3 juveniles; same data as for preceding; NatMIP-CMIs 0012.

\section{- Diagnosis}

Wide cephalon concave in the middle; 1 segmented antennular flagellum reaching beyond the end of the antennal peduncle, antennal flagellum with 7-9 segments (Figure 5B); pereonite 1 without coxal plate, coxal plates on other pereonites visible from dorsal view; pleotelson elongated and triangular [63].

\section{- Global Distribution}

Endemic to the Iberian Peninsula [64].

\section{- Distribution in Portugal}

Species recorded on the Minho River [16], Ria de Aveiro [34] and on the Mondego River [66].

\section{- Ecological Notes}

Poorly known brackish waters species.

\section{- Remarks}

Species only known from the Northwest Iberian Peninsula except for the single specimen collected on the Guadalquivir estuary [64] requiring further investigation on distribution and ecology of this species.

Family Idoteidae Samouelle, 1819

XII. Idotea chelipes (Pallas, 1766) (Figure 4D-F).

Idotea chelipes Naylor, 1972: 40, fig. 13B,E [7].

Synonyms: Oniscus chelipes Pallas, 1766: 194 Tab. XIV, fig. 16 [61].

Oniscus viridis Slabber, 1778: 104-106, Pl. XII, fig. 4-5 [66].

Idotea salinarium Dollfus, 1895: 39-40, fig. 21 [67].

Idotea angusta Sars, 1897: 83-84, Pl. XXXIV, fig. 2 [68].

Idothea viridis Sars, 1897: 83-84, Pl. XXXIV, fig. 2 [68].

Idotea viridis Collinge, 1917: 745, Pl. VII figs. 70-80 [69]; Naylor, 1955: figs. 1,2,7,8 [7].

\section{- Type Material}

DENMARK • Jutland Penisula [61]; Unknown data.

\section{- Material Examined}

PORTUGAL 1 adult with $12 \mathrm{~mm}$; International Minho River, Caminha; 4152'59.00”N / 850'14.00”W; 6 Apr. 2020; glass eel fishing bycatch; NatMIP-CMIs 0005 - 2 adults; same data as for preceding; NatMIP-CMIs $0006 \bullet 1$ adult specimen; same data as for preceding; NatMIP-CMIs $0007 \cdot 10$ adults, size range 5 to $12 \mathrm{~mm}$; same data as for preceding; NatMIP-CMIs 0008.

\section{- Diagnosis}

Body slender adult males ranging $15 \mathrm{~mm}$, adult females from 6 to $10 \mathrm{~mm}$; antennule extending well beyond article 3 of antennal peduncle (Figure 4E); antennal flagellum longer than the peduncle; narrow coxal plates, only those of pereonites 5-7 reaching the posterior border; pleotelson with sides subparallel, slightly curved in the mid-dorsal line; posterior border with a median tooth, hardly acute, and with obtuse lateral corners (Figure 4F) [7].

\section{- Global Distribution}

Northeast Atlantic from Norway down to Mediterranean [3].

\section{- Distribution in Portugal}

Recorded in Ria de Aveiro [36], and on the Tejo River [35].

\section{- Ecological Notes}

Brackish waters species common among intertidal waters in sheltered estuaries [7].

XIII. Stenosoma lancifer (Miers, 1881) (Figure 5C-D)

Stenosoma lancifer Dollfus 1897: 5, fig. 13 [71]

Synonyms: Idotea acuminata var. lanciformis Miers, 1881: 61 [70]

Idotea appendiculata Bate \& Westwood 1866: 396-397 [45]

Synisoma lancifer Collinge, 1917: 751, Pl. XI figs. 115-128 [69]; Naylor, 1972: 46, fig. 14B [7]

\section{- $\quad$ Type Material}

ENGLAND • Sidmouth [44]; Unknown data.

\section{- Material Examined}

PORTUGAL - 2 adults, size range from 24 to $27 \mathrm{~mm}$;

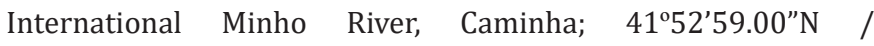
$8^{\circ} 50^{\prime} 14.00^{\prime \prime}$; 6 Apr. 2020; glass eel fishing bycatch; NatMIP-CMIs 0030 .

\section{- Diagnosis}

Pereon with triangular coxal plates and serrated lateral borders; pleotelson sides concave anteriorly, expanding about two-thirds of its length backwards, then narrowing sharply to an elongate median projection (Figure 5D); males up to 22-25mm, female smaller [7].

\section{- Global Distribution}

Northeast Atlantic coast from France to the Mediterranean and Southwest England [3].

\section{- Distribution in Portugal}

Species recorded along the West coast $[50,71]$

\section{- $\quad$ Ecological Notes}

Usually found around algae and under stones on Low Water Slack Tide (LWST) [3]. 


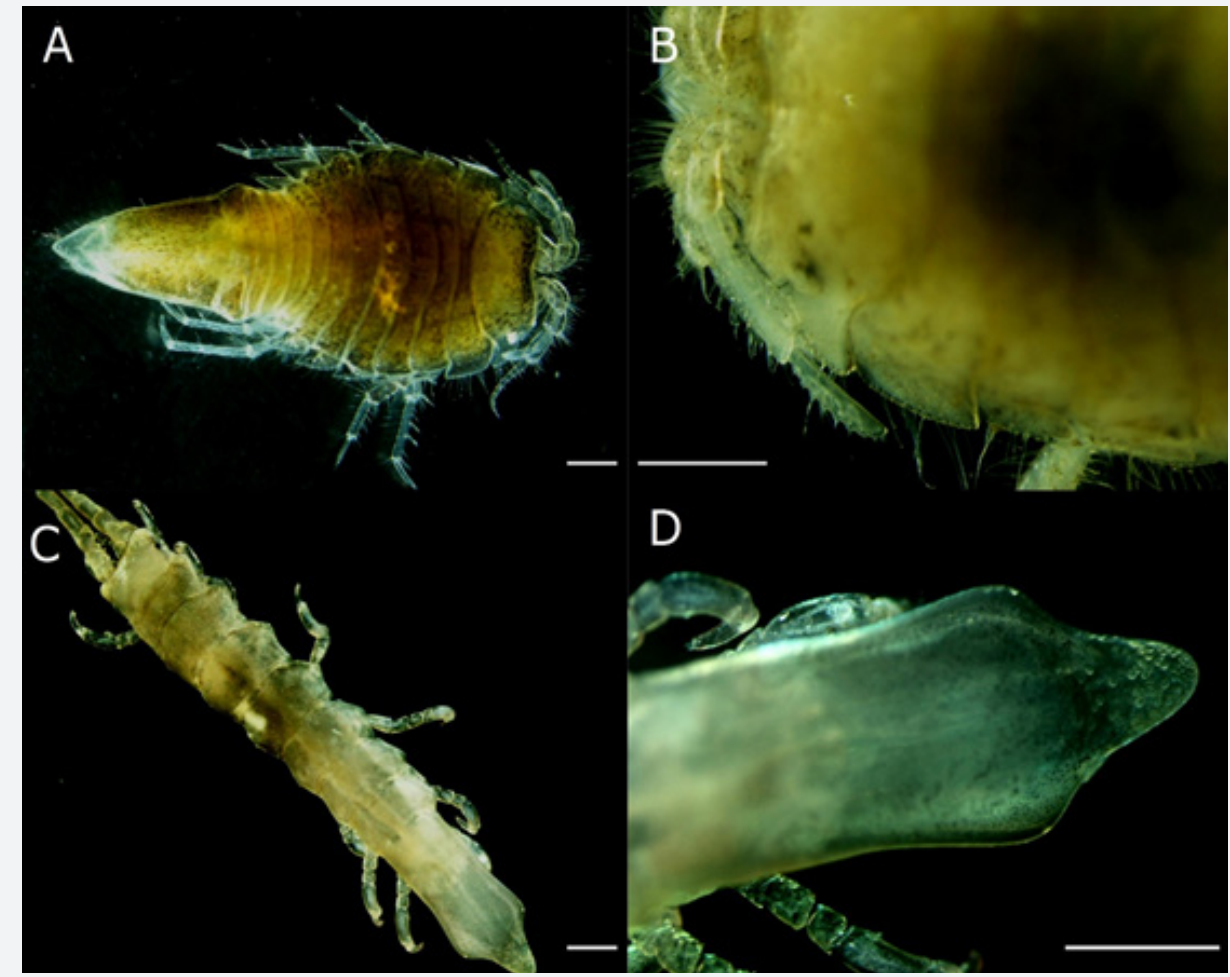

Figure 5: Saduriella losadai Holthuis, 1964: dorsal view (A), cephalon (B); Stenosoma lancifer (Miers, 1881): dorsal view (C), pleotelson (D). Scales: A-D: $1 \mathrm{~mm}$.

Key to the International Minho River isopod species

\begin{tabular}{|c|c|c|}
\hline \multirow[b]{2}{*}{1} & Uropods ventral forming an operculum covering the pleopods & 2 \\
\hline & Uropods lateral forming a caudal fan & 4 \\
\hline \multirow{2}{*}{2} & Pleon with 2 distinct segments & 3 \\
\hline & Pleon with 4 distinct segments; pleotelson triangular & Saduriella losadai \\
\hline \multirow{2}{*}{3} & $\begin{array}{l}\text { Pleon with two distinct segments plus one partially sutured with telson; pleotelson with expansion on middle } \\
\text { part }\end{array}$ & Stenosoma lancifer \\
\hline & $\begin{array}{l}\text { Pleon with two distinct segments plus one partially sutured with telson; body slender; antenna } 1 \text { extending } \\
\text { beyond article } 3 \text { of antenna } 2 \text { peduncle }\end{array}$ & Idotea chelipes \\
\hline \multirow{2}{*}{4} & With five pairs of pereopods and thoracomere 2 fused with cephalon & Paragnathia formica \\
\hline & With seven pairs of pereopods and thoracomere not fused with cephalon & 5 \\
\hline \multirow{2}{*}{5} & Body elongated nearly cylindrical; pereopod 1 subchelate & Cyathura carinata \\
\hline & Body not elongated, pereopod 1 neither enlarged or subchelate & 6 \\
\hline \multirow[t]{2}{*}{6} & $\begin{array}{l}\text { Pleon with five distinct somites plus one fused with telson; antennal peduncle with } 4 \text { articles; pleotelson with } \\
\text { round apical border; cromatophores only on dorsal surface }\end{array}$ & Eurydice affinis \\
\hline & Pleon with less than five distinct somites, more than one fused with telson & 7 \\
\hline \multirow{2}{*}{7} & Pereonite 6 without processes & 8 \\
\hline & Pereonite 6 with two elongated processes & 12 \\
\hline \multirow{2}{*}{8} & Telson posterior border rounded & 9 \\
\hline & Telson posterior border with a semi-circular slit & 13 \\
\hline \multirow{2}{*}{9} & Pereopods 1-3 and maxillipede palp with plumose setae; uropod exopod serrated & Spheroma serratum \\
\hline & Pereopods 1-3 and maxillipede palp with smooth setae & 10 \\
\hline
\end{tabular}


Oceanography \& Fisheries Open access Journal

\begin{tabular}{|c|c|c|}
\hline \multirow{2}{*}{10} & Uropod exopod with 6 or 7 teeth & Lekanesphaera levii \\
\hline & Uropod exopod smoth or with 2 or 3 teth & 11 \\
\hline \multirow{2}{*}{11} & Dorsal surface of pleotelson with two longitudinal rows of tubercles & Lekanesphaera hookeri \\
\hline & Dorsal surface of pleotelson granular & Lekanesphaera rugicauda \\
\hline \multirow[b]{2}{*}{12} & Pleotelson with two hemispherical bosses joined at the bases & Dynamene bidentata male \\
\hline & Pleotelson with two bosses joined by a short stem, each boss with apical projection & $\begin{array}{l}\text { Dynamene magnitorata } \\
\text { male }\end{array}$ \\
\hline \multirow{2}{*}{13} & Pleotelson with tubercles & Ischyromene lacazei \\
\hline & Pleotelson smooth & 14 \\
\hline \multirow{2}{*}{14} & Pleotelson rounded on side view & $\begin{array}{l}\text { Dynamene bidentata } \\
\text { female }\end{array}$ \\
\hline & Pleotelson with dorsal projection on side view & $\begin{array}{l}\text { Dynamene magnitorata } \\
\text { female }\end{array}$ \\
\hline
\end{tabular}

\section{Discussion}

All species collected are within the boundaries of their known distribution, although most of them are new records for the Minho River estuary, mainly due to the lack of information on macroinvertebrates for this specific area. From the 248 specimens collected, 245 come from glass eel fishing bycatch, with an expected higher number of species and individuals for this method due to the area covered by the net, with specimens being sampled from the top of the water column to the bottom, and marine species drifting towards the net due to the flood tides entering the estuary [16].

Except for the species Cyathura carinata (Krøyer, 1847), Saduriella losadai Holthuis, 1964, Lekanesphaera levii (Leach, 1814) and Sphaeroma serratum (Fabricius, 1787) $[15,16]$ all the other 9 species are new records for the international Minho River. The point of collection of $S$. serratum coincides with the samplings of this species $[15,14]$. Previous studies focused on ecological aspects, which contained lists of species, which in this manuscript some of these that were collected have been revised and morphologically described on taxonomic approach. Consequently, this is the first descriptive taxonomic study on Portuguese estuarine zone.

The most comparable study comes from Ria de Ferrol [72], on the Spanish Northwest coast approximately $200 \mathrm{~km}$ north from the Minho River estuary, where 39 isopod species were mentioned on a deep survey on the area studied. From the 13 species collected on the Minho River, 12 were also found on Ria de Ferrol only $S$. losadai being absent, with the northern most record on the Ulla River, Spain. A depth research is required to fully understand the composition and distribution of this group for the Portuguese coast, with different sampling methods concerning different habitats e assemblages.

\section{Conclusion}

This represents the first taxonomic study of Isopoda from the
International Minho River, contributing for isopod Portuguese and Iberian fauna, due to localization of this river. Bycatch method was efficient for sampling these animals, which possibly indicates that other species could appear if the sampling effort were greater and regular over time. Minho River presents potentialities, still unknown, mainly in the descriptive aspect, that still need to be discovered, in view of its importance and its strategic position, flowing into the Atlantic Ocean.

\section{Acknowledgements}

We thank the facilities provided by "Aquamuseu do Rio Minho", V.N. Cerveira, Portugal. We acknowledge the following for supplying specimens: fisherman Eduardo Martins, CIIMAR (Interdisciplinary Centre of Marine and Environmental Research) researcher Ester Dias, Duarte Martins (University of Porto). Special thanks to Pedro Vieira (University of Minho) for providing literature for species identification.

\section{References}

1. WORMS Editorial Board (2021) World Register of Marine Species.

2. Poore G C B, N L Bruce (2012) Global Diversity of Marine Isopods (Except Asellota and Crustacean Symbionts). PLoS One, 7: e43529.

3. Hayward P J, J S Ryland (2017) Handbook of the marine fauna of North-West Europe. In: P J Hayward, J S Ryland (eds.). ( $2^{\text {nd }}$ edn.) Oxford University Press, New York.

4. Wilson GD, RR Hessler (1974) Some Unusual Paraselloidea (Isopoda, Asellota) From The Deep Benthos Of The Atlantic. Crustaceana 27: 4767.

5. Lincoln R J, G A Boxshall (1983) Deep-sea asellote isopods of the north-east Atlantic: the family Dendrotionidae and some new ectoparasitic copepods. Zoological Journal of the Linnean Society 79(3): 297-318.

6. Nicholls GE (1943) The Phreatoicoidea: Part I. The Amphisopidae. Pap Proc R Soc Tasmania 1942 : 1-145.

7. Naylor E (1972) Synopses of the British Fauna British marine isopods: keys and notes for the identification of the species. In: ( $2^{\text {nd }}$ edn.) Academic Press, London.

8. Braga J M (1967) Trois Synasellus (Crust. Isopoda) nouveaux du Portugal Synasellus serranus sp nov Synasellus nobrei sp nov Synasellus minu- 
tus sp nov An da Fac Ciencias Univ.do Porto 50: 301-324.

9. Afonso O (1979) Un Proasellus (Crust. Isopoda) nouveau du Portugal An da Fac Ciencias Univ do Porto 61: 91-104.

10. Jones D A, C J Pierpoint (1997) Ecology and taxonomy of the genus Eurydice (Isopoda: Cirolanidae) from sand beaches on the Iberian Peninsula. Journal of the Marine Biological Association of the United Kingdom 77: 55-76.

11. Cunha M R, G L J Paterson, T Amaro, S Blackbird, H C De Stigter, et al. (2011) Biodiversity of macrofaunal assemblages from three Portuguese submarine canyons (NE Atlantic). Deep Sea Research Part II: Topical Studies in Oceanography 58(23-24): 2433-2447.

12. Cunha, Wilson G D F (2006) The North Atlantic genus Heteromesus (Crustacea: Isopoda: Asellota: Ischnomesidae). Zootaxa 1192: 1-76.

13. Cunha M, G D F Wilson (2003) Haplomunnidae (Crustacea: Isopoda) reviewed, with a description of an intact specimen of Thylakogaster Wilson \& Hessler, 1974. Zootaxa 326: 1-16

14. Weber M (1985) Zur Ökosystemstruktur des Minhoästuars, Iberische Westküste. PdD thesis. University of Kiel, Germany.

15. Mazé R A., M Lastra, J Mora (1993) Macrozoobentos del estuario del Mino (NO de Espana) Publicaciones Espec. Inst Español Ocean 11: 283-290.

16. Sousa R, S Dias, V Freitas, C Antunes (2008) Subtidal macrozoobenthic assemblages along the River Minho estuarine gradient (north-west Iberian Peninsula). Aquatic Conservation Marine Freshwater Ecosystems 18(7): 1063-1077.

17. Antunes C, M Weber (1996) The glass eel fishery and the by-catch in the Rio Minho after one decade (1981-1982 and 1991-1992). Fisheries \& Aquatic Life 4: 131-139.

18. APA (2016) Plano de gestão de região hidrográfica - região hidrográfica do Minho e Lima (Rh1) (Lisboa)

19. Sousa R, L Guilhermino, C Antunes (2005) Molluscan fauna in the freshwater tidal area of the River Minho estuary, NW of Iberian Peninsula. Annales de Limnologie - International Journal of Limnology 41(2): 141-147

20. Dias E, P Morais, C Antunes, J C Hoffman (2014) Linking terrestrial and benthic estuarine ecosystems: organic matter sources supporting the high secondary production of a non-indigenous bivalve. Biological Invasions 16: 2163-2179.

21. Birdlife International (2021) Important Bird Areas factsheet: Minho and Coura estuaries.

22. Blott S J, K Pye (2001) Gradistat: A grain size distribution and statistics package for the analysis of unconsolidated sediments. Earth Surface Process and Landforms 26(11): 1237-1248.

23. Naylor E (1955) The comparative external morphology and revised taxonomy of the British species of Idotea. Journal of the Marine Biological Association of the United Kingdom 34: 467-493.

24. Holdich D M (1968) A systematic revision of the genus Dynamene (Crustacea: Isopoda) with descriptions of three new species. Pubbl Stn Zool di Napoli 36: 401-426.

25. Leach W E (1814) Crustaceology. In: D Brewster (ed.). The Edinburgh Encyclopaedia, Balfour, Edinburgh.

26. Kröyer H (1847) Karcinologiste Bidrag (Fortsaettelse). Naturhistorisk Tidsskr Ser II 2: 366-466.

27. Richardson H (1905) A monograph on the isopods of North America. Bulletin of the United States. Bull. United States Natl. Museum 54
$1-727$.

28. Cléret J J (1960) Étude de Cyathura carinata (Kröyer) (Isopode Anthuridae): 1 . Redescription de lespèce et discussion systématique. Cah Biol Mar 1: 433-452.

29. Verrill AE, Smith SI, Harger O (1873) Catalogue of the marine invertebrate animals of the southern coast of New England, and adjacent waters. Report upon the invertebrate animals of Vineyard Sound and adjacent waters, with an account of the physical features of the region.

30. Boyko C B, N L Bruce, K A Hadfield, K L Merrin, Y Ota, et al. (2021a) Cyathura carinata (Krøyer, 1847). World Mar Freshw Terr Isopod Crustac.

31. Sousa R, S Dias, J C Antunes (2006) Spatial subtidal macrobenthic distribution in relation to abiotic conditions in the Lima estuary, NW of Portugal. Hydrobiologia 559: 135-148.

32. Carvalho A N, P T Santos (2013) Factors affecting the distribution of epibenthic biodiversity in the Cávado estuary (NW Portugal). Rev Gestão Costeira Integr 13(1): 101-111.

33. Mucha A P, M T S D Vasconcelos, A A Bordalo (2003) Macrobenthic community in the Douro estuary: Relations with trace metals and natural sediment characteristics. Environmental Pollution 121(2): 169180.

34. Marques JC, Martins I, Teles-Ferreira C C S (1994) Population Dynamics, Life History, and Production of Cyathura carinata (Krøyer) (Isopoda: Anthuridae) in the Mondego Estuary. Journal of Crustacean Biology 14(2): 258-272.

35. Salgado J P, H N Cabral, M J Costa (2004) Feeding ecology of the gobies Pomatoschistus minutus (Pallas, 1770) and Pomatoschistus microps (Krøyer, 1838) in the upper Tagus estuary, Portugal. Scientia Marina 68: 425-434.

36. Cunha M, J Sorbe, M Moreira (1999) Spatial and seasonal changes of brackish peracaridan assemblages and their relation to some environmental variables in two tidal channels of the Ria de Aveiro (NW Portugal). Marine Ecology Progress Series 190: 69-87.

37. Martins I, S Cruz, J C Marques, S Gamito (2003) Autecology of the isopod, Cyathura carinata (Krøyer, 1847) in the Ria Formosa (Algarve Portugal). Crustaceana 76: 781-802.

38. Carvalho S, A Moura, J Cúrdia, L Cancela Da Fonseca, M N Santos (2013) How complementary are epibenthic assemblages in artificial and nearby natural rocky reefs? Marine Environmental Research 92: 170-177.

39. Wolff W J (1966) Notes on Eurydice (Isopoda, Flabellifera) from the Netherlands. Zool Meded 41: 221-227.

40. Robert J, R J Medeiros, A L Pollard (2006) Evidence for foraging by nocturnal inter-tidal European Storm-petrels Hydrobates pelagicus during migration. Atlantic Seabirds 8: 87-96.

41. Castro M L F, M Do C Viegas (1983) Estudo dos povoamentos de algas fotófilas da Ilha De S. Miguel (Açores). Arquipélago, Série Ciências da Nat 4: 7-30

42. Borges P A V, A Costa, R Cunha, R Gabriel, V Gonçalves, et al. (2010) Biologia Listagem dos organismos terrestres e marinhos dos açores - $\mathrm{A}$ List of the terrestrial and marine biota from the azores.

43. Hesse E (1864) Mémoire sur les pranizes et les ancées et sur les moyens curieux à l aide desquels certains crustacés parasites assurent la conservation de leur espèce. Imprimerie Imperiale.

44. Naylor E (1957) Isopoda. Sub-Order: Flabellifera, Family: Gnathidae Genera: Paragnathia, Gnathia, Family: Cirolanidae, Genus: Eurydice. Fiches d'identification du zooplancton. 78. 
45. Bate C S, J O Westwood (1866) A History of the British Sessile-eyed Crustacea. In: John Van Voorst, London, Pp. 1863-1868.

46. Chainho P, J L Costa, M L Chaves, M F Lane, D M Dauer, et al. (2006) Seasonal and spatial patterns of distribution of subtidal benthic invertebrate communities in the Mondego River, Portugal - A poikilohaline estuary. Hydrobiologia 555: 59-74.

47. Adams J (1800) Description of some marine animals found on the coast of Wales. Transactions of the Linnean Society of London 5: 7-13.

48. Holdich D M (1970) The distribution and habitat preferences of the afro-european species of Dynamene (Crustacea: Isopoda). Journal of Natural History 4: 419-438.

49. Holdich D M (1976) A comparison of the ecology and life cycles of two species of littoral isopod. Journal of Experimental Marine Biology and Ecology 24(2): 133-149.

50. Vieira P E, H Queiroga, F O Costa, D M Holdich (2016) Distribution and species identification in the Crustacean isopod genus Dynamene Leach, 1814 along the North East Atlantic-Black Sea axis. Zookeys 635: 1-29.

51. Pereira S G, F P Lima, N C Queiroz, P A Ribeiro, A M Santos (2006) Biogeographic patterns of intertidal macroinvertebrates and their association with macroalgae distribution along the Portuguese coast. Hydrobiologia 555: 185-192.

52. Boyko C B, N L Bruce, K A Hadfield, K L Merrin, Y Ota, et al. (2021b) Dynamene magnitorata (Holdich, 1968). World Mar Freshw Terr Isopod Crustac.

53. Racovitza E G (1908) Ischyromene Lacazei n. g., n. sp. Isopode mediterraneen de la famille des Spheromides (Note preliminaire). Arch Zool Exp Gen Notes Rev 9: 60-64.

54. Schuller M, J W Wagele (2005) Redescription of Ischyromene lacazei Racovitza, 1908 (Isopoda: Sphaeromatidae) from the Mediterranean Coast of southern France. Organisma Diversity Evolution 5(2): 165166.

55. Jacobs B (1987) A taxonomic revision of the european, mediterranean and nw. african species generally placed in Sphaeroma Bosc, 1802 (Isopoda: Flabellifera: Spaeromatidae). Zoologische Verhandelingen 238(1): 1-71.

56. Jansen K P (1970) Effect of temperature and salinity on survival and reproduction in baltic populations of sphaeroma hookeri leach, 1814 and S.Rugicauda leach, 1814 (ISOPODA). Ophelia 7: 177-184.

57. Colosi G (1921) Missione zoologica del Dott E Festa in Cirenaica Crostacei Boll Musei di Zool ed Anat Comp 739(36): 1-6.

58. Argano R, A Ponticelli (1981) Nomenclature e geonemia di Sphaeroma monodi Arcangeli, 1934, del Mediterraneo e del Mar Nero (Crustacea, Isopoda Flabellifera). Bolletino del Mus Civ di Stor Nat di Verona 1980: 227-234.

59. Boyko C B, N L Bruce, K A Hadfield, K L Merrin, Y Ota, et al. (2021d) Lekanesphaera levii (Argano \& Ponticelli, 1981). World Mar Freshw Terr Isopod Crustac.
60. Carvalho S, P Pereira, F Pereira, H De Pablo, C Vale, et al. (2011) Factors structuring temporal and spatial dynamics of macrobenthic communities in a eutrophic coastal lagoon (Óbidos lagoon, Portugal). Mar Environ Res 71(2): 97-110.

61. Fabricius J C (1787) Mantissa insectorum sistens eorum species nuper detectas adjectis characteribus genericis differentiis specificis, emendationibus, observationibus. Tome I. (Hafniae: Christ. Gottl. Proft).

62. Pallas P S (1766) Miscellanea zoologica. Quibus novae imprimis atque obscurae animalium species describuntur et observationibus iconibusque illustrantur. Petrum van Cleef. Hagí Comitum.

63. Holthuis L B (1964) Saduriella, a new genus of Isopoda Valvifera from Northwestern Spain. Zoologische Mededelingen 40(6): 29-35.

64. Baldó F, C Megina, J Cuesta (2000) Saduriella losadai Holthuis, 1964 (Isopoda, Valvifera) in the Guadalquivir Estuary (S.W. Spain). Crustaceana 73: 1015-1017.

65. Graça M A, M Â Pardal, J C Marques (2002) Aquatic ecology of the Mondego River basin global importance of local experience. Imprensa da Universidade de Coimbra.

66. Slabber M (1778) Natuurkundige Verlustigingen, behelzende microscopise Waarnemingen van in - en utilandse Water - en Land-Dieren.

67. Dollfus A (1895) Les Idoteidae des côtes de France. Feuille des Jeunes Nat 25: 1-5.

68. Sars G O (1897) An account of the Crustacea of Norway with short descriptions and figures of all the species. In: B Museum (ed.). Volume II. Isopoda (Bergen).

69. Collinge W E (1917) A Revision of the British Idoteidae, a Family of Marine Isopoda. Earth and Environmental Science Transactions of The Royal Society of Edinburgh 51(3): 721-760.

70. Miers E J (1881) Revision of the Idoteidae, a family of sessile-eyed Crustacea. Journal of the Linnean Society of London, Zoology 16(89): 1-88.

71. Dollfus A (1897) Sur deux types nouveaux de Crustaces Isopodes appartenant a la faune souterraine des Cevennes. Comptes rendus Hebd. Seances l Academie des Sci Paris 125: 130-131.

72. Xavier R, A M Santos, M Branco (2012) MtDNA and nuclear data reveal patterns of low genetic differentiation for the isopods Stenosoma lancifer and Stenosoma acuminatum, with low dispersal ability along the northeast Atlantic coast. Scientia Marina76: 133-140.

73. Reboreda P, V Urgorri (1995) Nuevos datos sobre los Isópodos (Crustacea: Peracarida) en las costas del noroeste de la Península Ibérica. Graellsia 51: 129-141.

74. Boyko C B, N L Bruce, K A Hadfield, K L Merrin, Y Ota, et al. (2021c) Eurydice affinis (Hansen, 1905). World Mar Freshw Terr Isopod Crustac.

75. Hansen H J (1908) Revision of the European forms of the Cirolaninae, a subfamily of Crustacea, Isopoda. J Linn Soc Zool 29: 337-373. 
This work is licensed under Creative Commons Attribution 4.0 Licens

DOI: 10.19080/OFOAJ.2021.13.555866
Your next submission with Juniper Publishers will reach you the below assets

- Quality Editorial service

- Swift Peer Review

- Reprints availability

- E-prints Service

- Manuscript Podcast for convenient understanding

- Global attainment for your research

- Manuscript accessibility in different formats ( Pdf, E-pub, Full Text, Audio)

- Unceasing customer service

Track the below URL for one-step submission https://juniperpublishers.com/online-submission.php 